\title{
The illusion of ethics for good local governance in South Africa
}

\author{
$S$ VYAS-DOORGAPERSAD \& EP ABABIO*
}

\begin{abstract}
Ethics, the legislation and upholding of good conduct by public officials is a sine qua non for sustenance of good governance and service delivery. The White Paper on the Transformation of the Public Service 1994 identified the need for a code of conduct in South Africa as an essential element to enhance high standards of ethics and professionalism. In 1996, the Constitution of the Republic of South Africa prescribed the values and principles of Public Administration. Subsequently, the Public Service Commission developed a Code of Conduct in 1997. The legitimacy of local government is based on the same principles of ethics and professionalism as that of the national government. It is imperative to implement an ethical framework for social and economic development at the grass-root level. This article examines the theoretical terrain of ethics in public management and posits that, whereas there exist some state-of-the-art legislation that regulate the conduct of public functionaries at the local government sphere, outcomes of ethics in practice are rather unethical and illusive. There is therefore an advocacy for the need to intensify implementation of ethical guidelines for councillors and municipal employees. The fiduciary, management, operational and accountability framework is further upheld through the implementation of a code of conduct for local officials. Theoretically, the framework should be scientifically accountable and practically feasible in implementation.

The article recommends the need to strategise measurable implementation plans, conduct the on-going fraud risk assessments and sensitise the community through education and training regarding good governance and the code of ethics. The approach used is descriptive, though analytical.
\end{abstract}

Keywords: ethics, corruption, good local governance, code of conduct.

Disciplines: Public management and governance, Ethics.

Proff. Ernest Ababio and Shikha Vyas-Doorgapersad are both attached to the subject group for Public Management and Administration, School of Basic Sciences at North-West University'sVaal Triangle Campus in Vanderbijlpark. They can be contacted at: the following emails: Ernest.Ababio@nwu.ac.za and/ord Shikha.VyasDoorgapersad@nwu.ac.za 


\section{Introduction}

The image of a government depends upon the conduct of public functionaries and the perceptions of its citizenry regarding the acceptable standards of services offered by the functionaries. It is, therefore, of fundamental importance that

public functionaries act justly and fairly to one and all, not only paying lip service to transparency and openness (Vyas-Doorgapersad \& Ababio, 2006: 385),

but also ensure that these are manifested based on Batho Pele principles per se. It is imperative that each public functionary, upon accepting government employment, takes cognizance of the fact that there is a special duty to be open, fair and impartial in interacting with the public.

Ethical standards and behaviour expectations of public servants are usually spelt out in a code of ethics normally documented in rules and regulations. They are also implicit in the behaviour that may constitute an act of misconduct that may manifest itself in various forms and at different times in the history of the state (Agere, 1992: 39). In order to improve the ethical environment at individual and institutional level, it is imperative to understand and compare the traditional ethical system to the current one. The table below, as identified by Sardar (Raga and Taylor, 2007: 9) is a comparison of public service ethics in the twentieth-century with envisaged public service ethics for the twenty-first century.

Table 1: Traditional and Modern Public Service Ethics

\begin{tabular}{|l|ll|}
\hline Twentieth-century ethics & Twenty-first-century ethics \\
\hline Determinants-ruling elites & $\begin{array}{l}\text { Determinants-authentic discourse among all } \\
\text { who will be affected }\end{array}$ \\
\hline $\begin{array}{l}\text { Common ethical code-belief in final } \\
\text { solutions }\end{array}$ & $\begin{array}{l}\text { Constantly managing code(s)-based on } \\
\text { continuous authentic discourse }\end{array}$ \\
\hline Support guaranteed through coercion & Support guaranteed through consensus & \\
\hline Dissenters subject to punitive measures & Dissenters subject to punitive measures \\
\hline Western (colonial) ethics & $\begin{array}{l}\text { Ethics based on anthropological and } \\
\text { sociological pluralism }\end{array}$ \\
\hline $\begin{array}{l}\text { Corporate accountability (amounts to non- } \\
\text { accountability) }\end{array}$ & Personal accountability \\
\hline $\begin{array}{l}\text { Exercise of personal morality stifled and } \\
\text { discouraged }\end{array}$ & Exercise of personal morality encouraged \\
\hline Exercise of personal discretion discouraged & Exercise of discretion encouraged \\
\hline $\begin{array}{l}\text { Public interest nebulous, determined by } \\
\text { governing elites }\end{array}$ & $\begin{array}{l}\text { Public interest(s) disparate but relatively } \\
\text { distinct, determined with all involved } \\
\text { (authentic discourse), constantly redefined }\end{array}$ \\
\hline
\end{tabular}

The table explores the fact that the new century seems to dawn with a renewed load of ethical and philosophical dilemmas which leave practitioners and academics of public administration alike in a predicament. Whereas at the beginning of the $20^{\text {th }}$ century there seemed to be only answers and convictions, at the beginning of the new century we are surrounded by new questions, uncertainties and doubts resulting from the overarching processes of the globalisation of market economies and information technology as well as the localisation of political conflict, authority systems and culture (Makrydemetres, 2002: 3). This paradigmatic shift furthermore raises debate regarding the exercise of ethics at decentralized levels of authority and how 
applicable these ethical codes are in creating an environment of good governance. The following sections are built on the pieces of information searching for measures to avoid ethical dilemmas for moral regeneration of public functionaries at the South African municipal sphere.

\section{Meaning and nature of concepts ethics and good governance}

Coicaud and Warner (in Walters, 2009:1) commented that ethics is concerned with what is essentially human in our nature. In thinking and acting in an ethical manner, the individual makes himself a witness to what positively distinguishes humans: the quest for dignity. Ethics therefore is not about the self in isolation but fundamentally has a social quality Freakley and Burgh (in Cranston et al., 2003: 1) see ethics as 'about what we ought to do'. These perspectives imply that an ethical judgement often may need to be made about a given problem or situation (Cranston et al, 2003: 1). There is the inference that functionaries
may often be faced with choices that require them to make decisions that have no clear cut resolution and are likely to be highly problematic. That is, they are likely to find themselves confronted with ethical dilemmas. Simply put then, an ethical dilemma, arises from a situation that necessitates a choice among competing sets of principles, values, beliefs, perspectives (Cranston et al, 2003: 1).

In other words, ethics is normative; it is the exercise of a capacity to discriminate among available courses of action on the basis of interpretation of shared values embedded in an ongoing institutional practice and in a broader form of communal life (Jennings, in Sindane, 2009:500).

Good governance includes ten principles as requisites of ethical local governance These principles are:

- Participation: to encourage all citizens to exercise their right to express their opinion in the process of making decisions concerning the public interest, both directly and indirectly;

- Rule of Law: to realise law enforcement which is fair and impartial for all, without exception, while honouring basic human rights and observing the values prevalent in the society;

- Transparency: to build mutual trust between the government and the public through the provision of information with guaranteed easy access to accurate and adequate information;

- Equality: to provide equal opportunities for all members of the society to improve their welfare;

- Responsiveness: to increase the sensitivity of government administrators to the aspirations of the public;

- Vision: to develop the region based on a clear vision and strategy, with participation of the citizenry in all the processes of development so that they acquire a sense of ownership and responsibility for the progress of their regions; 
- Accountability: to increase the accountability of decision-makers with regard to decisions in all matters involving the public interest;

- Oversight: to increase the efforts of supervision in the operation of government and the implementation of development by involving the private sector and the general public;

- Efficiency and Effectiveness: to guarantee public service delivery by utilizing all available resources optimally and responsibly; and

- Professionalism: to enhance the capacity and moral disposition of government administrators so that they are capable of providing easy, fast, accurate and affordable services. These principles are imperatives to enhance ethical environment for good local governance (United Nations Development Programme, 2008; Vyas-Doorgapersad, Subban \& Pillay, 2008).

The elements of good governance can be hampered by several types of political corruption that occur in local government. Some are more common than others, and some are more prevalent to local governments than to larger segments of government. Local governments may be more susceptible to corruption because interactions between private individuals and officials happen at greater levels of intimacy and with more frequency at more decentralized levels. Forms of corruption pertaining to money like bribery, extortion, embezzlement, and graft are found in local government systems. Other forms of political corruption are nepotism and patronage systems (PoliticalCorruption.net, 2009). Political corruption creates ethical dilemmas at grassroot level. This has been highlighted by ex-President Thabo Mbeki when he laments that

...some of the people who are competing to win nomination as our candidate local government councillors are obviously seeking support on the basis that once they are elected to positions of power, they will have access to material resources and the possibility to dispense patronage.

He added:

These goings-on tell the naked truth that the ranks of our movement are being corrupted by a self-seeking spirit that leads some among us to view membership of our organisation as a stepping stone to access to state power, which they would then use corruptly to plunder the people's resources for their personal benefit (ANC Today, 2005; DA, 2010: 2).

The factors that can cause corruption in local government are discussed in the next section.

\section{Causes of corruption in local government}

The South African Prevention of Corruption Act, 1992, defined the term corruption as

any person deemed guilty of a corruptible offence whenever such a person corruptly accepts, obtains, or agrees to accept any gift as an inducement or reward for himselflherself or any other person, the result of such an action leading to favour or disfavour being shown to the party offering the inducement; and any person who corruptly gives or accepts any gift from a party as an inducement or reward for rendering services on behalf and in favour of the designated party.

Corruption therefore symbolize any conduct or behaviour in relation to persons entrusted with responsibilities in public office which violates their duties as public officials an which is aimed at 
obtaining undue gratification of any kind for themselves or for others (Department of Public Service and Administration, 2002; Vyas-Doorgapersad, 2007: 286).

Socioeconomic characteristics, size of the population and infrastructure development potential in municipalities are some of the encouraging causes of corruption at grass-root level. The Democratic Alliance (DA) report titled "The rot in ANC municipalities: five case-studies of cronyism, corruption and ineptitude" emphasized that

(A) major problem facing many municipalities is the small revenue base in the poorer areas. This is largely a structural problem that cannot be blamed on councillors and municipal officials. However, all efforts to overcome this stumbling block are being undermined by three key factors that are wholly avoidable: corruption, financial mismanagement and the appointment of senior officials solely on the basis of political connectivity andlor employment equity considerations. Municipal Managers tend to be under qualified, overpaid and consequently do not perform" (DA, 2010: 1).

The extract from the DA report reveals the following facts regarding corruption in South African municipalities:

- local government has become virtually synonymous with illegal tendering practices, unauthorised loans to councillors and, in some cases, outright looting. A recent Gautengbased survey on local government revealed that sixty percent of the residents profiled expressed concern over what they perceived as high levels of corruption in their municipality. Intense rivalries in the ANC have developed for positions in local bureaucracies and seats in councils because of the spoils on offer once appointed or elected.

- the inability of many municipalities to comply with financial regulations set by the Auditor-General is a disturbing indicator of the lack of capacity in many municipalities.

- another indicator of financial misconduct is the failure to collect enough revenue to pay for service delivery.

- it is generally accepted that municipalities should spend no more than $30 \%$ of their budget on salaries and the other $70 \%$ should go to infrastructure and service delivery. However, the amount paid in salaries to councillors and municipal officials outstrips spending on services by nearly R10 billion $-10 \%$ of the total municipal budget. Some Municipal Managers have been known to earn in the region of R1.2 million, although the national average is closer to the R650 000 mark before performance bonuses. The issue with salaries and bonuses is not just the amount of money, but the fact that Municipal Managers are often rewarded despite their failure to run a municipality properly" (DA, 2010: 1-3).

The cases of corruption in South African municipalities are available at http://www.da.org.za.

There has been a marked increase in unethical conduct and corruption in local government in South Africa in the past five years. The Government has acknowledged that the matter has to be addressed as a matter of urgency in South Africa as it impacts negatively on service delivery. The Republic of South Africa Constitution Act of 1996 provides the constitutional basis for promoting ethical conduct. The Local Government Municipal Structures Act 117 of 1998 has 
ushered in a code of conduct for councillors, while the Local Government: Municipal Systems Act 32 of 2000 has introduced a code of ethics for officials. It is expected that the abovementioned codes will present challenges to both local politicians and officials in setting up the culture of an ethical and corruption-free environment in local government. Within this framework and the broader context of local government, the community and municipal functionaries will have to seriously take cognisance of the institutional and administrative measures on hand to enhance ethical conduct and counter corruption. The curbing of corruption and enhancing of ethical conduct would, in the final analysis, ensure that the public interest is promoted and protected by addressing the needs and desires of the local citizenry (Democracy Development Programme, 2006).

The subject of ethics in South African local government has always evoked a great degree of interest in our relatively new democracy, particularly, as the local sphere of government is much closer to local communities compared to its provincial and national counterparts. It is also not uncommon for members of the public to view councillors and municipal staff members with suspicion and distrust, which is often attributable to past experiences of improper conduct on the part of certain individuals. It is for this reason that transparency and accountability tend to form the cornerstone of any legislation dealing with local government (Nkosi, 2006). The framework of ethics for good local governance in South Africa, explored in the next section.

\title{
Ethical conduct at the local sphere in South Africa
}

The Code of Ethics is a requisite for good local governance in South Africa. The purpose of Municipal Code of Ethics is

\begin{abstract}
to ensure transparency and ethical conduct by government employees and officials; to restore or foster public trust and citizen confidence in the administration of government; and to demonstrate a formal and codified commitment to ethical behaviour by government officials (Un-Habitat, 2004).
\end{abstract}

The office of the Public Service Commission initially issued a Code of Conduct for public servants as a Government Notice/Gazette: Regulation Gazette 5947, No. R. 825, on June 10 1997. The code of conduct provides guidelines to both public officials and employers of what type of ethical behaviour is expected of them. The code also gives an indication of the spirit in which public officials should perform their duties; the action to take to avoid conflict of interest; and the terms of public official's personal conduct and private interest (Cameron \& Stone, 1995: 80). A code of conduct for the public service officials at national, provincial and local government levels includes (Public Service Commission, 2010):

Relationship with the legislature and the executive: An employee is faithful to the Republic and honours the Constitution and abides thereby in the execution of her or his daily tasks; puts the public interest first in the execution of her or his duties; loyally executes the policies of the government of the day in the performance of her or his official duties as contained in all statutory and other prescripts; strives to be familiar with and abides by all statutory and other instructions applicable to her or his conduct and duties; and co-operates with public institutions established under legislation and the Constitution in promoting the public interest.

Relationship with the public: An employee promotes the unity and well-being of the South African nation in performing her or his official duties; will serve the public in an unbiased and 
impartial manner in order to create confidence in the public service; is polite, helpful and reasonably accessible in her or his dealings with the public, at all times treating members of the public as customers who are entitled to receive high standards of service; has regard for the circumstances and concerns of the public in performing her or his official duties and in the making of decisions affecting them; is committed through timely service to the development and upliftment of all south Africans; does not unfairly discriminate against any member of the public on account of race, gender, ethnic or social origin, colour, sexual orientation, age, disability, religion, political persuasion, conscience, belief, culture or language; does not abuse her or his position in the public service to promote or prejudice the interest of any political party or interest group; respects and protects every person's dignity an her or his rights as contained in the Constitution; and recognize the public's right of access to information, excluding information that is specifically protected by law.

Relationships among employees: An employee co-operates with other employees to advance the public interest; executes all reasonable instructions by persons officially assigned to give them, provided these are not contrary to the provisions of the Constitution and/or any other law; refrains from favouring relatives and friends in work-related activities and never abuses her or his authority or influences another employee, nor is influenced to abuse her or his authority; uses the appropriate channels to air her or his grievances or to direct representations; is committed to the optimal development, motivation and utilization of her or his staff and the promotion of sound labour and interpersonal relations; deals fairly, professionally and equitably with other employees, irrespective of race, gender, ethnic or social origin, colour, sexual orientation, age, disability, religion, political persuasion, conscience, belief, culture or language; and refrain from party political activities in the workplace.

Performance of duties: An employee strives to achieve the objectives of her or his institution cost effectively and in the public's interest; is creative in thought and in the execution of her or his duties, seeks innovative ways to solve problems and enhances effectiveness and efficiency within the context of the law; is punctual in the execution of her or his duties; executes her or his duties in a professional and competent manner; does not engage in any transaction or action that is in conflict with or infringes on the execution of her or his official duties; will rescue herself or himself from any official action or decision-making process which may result in improper personal gain, and this should be properly declared by the employee; accepts the responsibility to avail herself or himself of ongoing training and self-development throughout her or his career; is honest and accountable in dealing with public funds and uses the public service's property and other resources effectively, efficiently, and only for authorized official purposes; promotes sound, efficient, effective, transparent and accountable administration; in the course of her or his official duties, shall report to the appropriate authorities fraud, corruption, nepotism, maladministration and any other act which constitutes an offence, or which is prejudicial to the public interest; gives honest and impartial advice, based on all available relevant information, to higher authority when asked for assistance of this kind; and honours the confidentiality of matters, documents and discussions, classified or implied as being confidential or secret.

Personal conduct and private interests: An employee during official duties, dresses and behaves in a manner that enhances the reputation of the public service; acts responsibly as far as the use of alcoholic beverages or any other substance with an intoxicating effect is concerned; does not use her or his official position to obtain private gifts or benefits for herself or himself during the performance of her or his official duties nor does she or he accept any gifts or benefits when offered as these may be construed as bribes; does not use or disclose any official information for 
personal gain or the gain of others; and does not, without approval, undertake remunerative work outside her or his official duties or use office equipment for such work.

\section{Significance of code of conduct/ethics}

Promoting ethical standards in the public sector is a function of implementation and oversight of a code of conduct. Such regulatory practice conforms to specific norms namely (Urban Governance Toolkit Series, 2004):

Creation: The process of producing a code of ethics must itself be an exercise in ethics. It must intentionally involve all members of the social group that it will include and represent. This necessitates a system or process of setting out "from top to bottom", from the sundry to the specific, and constitutes progressive agreements in such a way that the final result is recognized a representative of all the moral and ethical character of the group;

Determining jurisdiction: Municipalities need to designate individuals responsible for establishing enforcement guidelines and advisory procedures, and subsequently, including named entity within the code of ethics;

Disseminating the Code of Ethics: Municipal employees and officials must understand the rules, obligations and expectations of standards to which they must abide;

Co-ordinating inter-government support: The relevant municipal stakeholder needs to strategize enforcement, communication and administrative support; and

Establishing a library of decisions and opinions: The transparent element of a code of ethics is best effectuated through cogent opinions and decisions interpreting the various laws and provisions. Understanding the application of the code is an important element for transparent municipal governance.

In addition to a code of ethics, provision is also made among the doctrines of democracy for the conduct of public officials. As pointed out by Cloete (1995: 187-188),: it is generally accepted that public officials must promote the general welfare of the public in accordance with policy determined by the legislator; public officials, according to the doctrine of democracy, must in performing their duties, respect the rights and freedom of the population, whose rights and freedom can only be infringed upon directly by the legislator; the public should always be able to demand public officials to give account of their activities; in a democratic state, every member of the population has the right to insist on fair and reasonable treatment; and the activities of public officials can meet the ethical norms only if they fulfil their activities effectively without wasting the resources of the community.

\section{Lessons learnt}

A number of countries implement some effective tools to enhance good local governance. The strategies and tools to support good governance at local level are specified in the table below (Un-Habitat, 2004): 
Table 2: Strategies and tools to support good governance at local sphere

\begin{tabular}{|c|c|c|c|c|}
\hline STRATEGIES & $\begin{array}{l}\text { Assessment and } \\
\text { Monitoring }\end{array}$ & $\begin{array}{lr}\text { Access } & \text { to } \\
\text { information and } \\
\text { public } \\
\text { participation }\end{array}$ & $\begin{array}{l}\text { Promoting ethics, } \\
\text { professionalism } \\
\text { and integrity }\end{array}$ & Institutional reforms \\
\hline \multirow[t]{8}{*}{ TOOLS } & $\begin{array}{l}\text { The Municipal } \\
\text { Checklist } \\
\text { e.g. Namibia, } \\
\text { Greece }\end{array}$ & $\begin{array}{l}\text { Public Meetings } \\
\text { e.g. Wisconsin }\end{array}$ & $\begin{array}{l}\text { Conflict of Interest } \\
\text { Laws } \\
\text { e.g. USA }\end{array}$ & $\begin{array}{l}\text { Complaints and } \\
\text { Ombudsman Office } \\
\text { e.g. Northern Ireland, } \\
\text { Canada, Germany }\end{array}$ \\
\hline & $\begin{array}{l}\text { The Urban } \\
\text { Corruption Survey } \\
\text { e.g. Kenya, Brazil }\end{array}$ & $\begin{array}{l}\text { Open Meeting Laws } \\
\text { e.g. United States, } \\
\text { Arizona }\end{array}$ & $\begin{array}{l}\text { Disclosure of } \\
\text { Income and Assets } \\
\text { e.g. USA }\end{array}$ & $\begin{array}{ll}\text { Municipal } & \text { Front } \\
\text { Office } & \\
\text { e.g. Kosovo } & \\
\end{array}$ \\
\hline & $\begin{array}{l}\text { The Municipal } \\
\text { Vulnerability } \\
\text { Assessment } \\
\text { e.g. Washington, } \\
\text { DC }\end{array}$ & $\begin{array}{l}\text { Access to } \\
\text { Information Laws } \\
\text { e.g. South Africa }\end{array}$ & $\begin{array}{l}\text { Lobbyist } \\
\text { Registration } \\
\text { e.g. USA }\end{array}$ & $\begin{array}{l}\text { One Stop Shop } \\
\text { e.g. Australia, UK }\end{array}$ \\
\hline & $\begin{array}{l}\text { Participatory } \\
\text { Corruption } \\
\text { Appraisal } \\
\text { e.g. Indonesia }\end{array}$ & $\begin{array}{l}\text { Records } \\
\text { Management and } \\
\text { Computerization } \\
\text { e.g. India, New } \\
\text { Guinea }\end{array}$ & $\begin{array}{ll}\text { Whistle } & \text { Blower } \\
\text { Protection } & \\
\text { e.g. USA } & \end{array}$ & $\begin{array}{l}\text { Oversight Committees } \\
\text { e.g. USA }\end{array}$ \\
\hline & $\begin{array}{l}\text { Report Cards } \\
\text { e.g. India, Filipino, } \\
\text { Bangladesh }\end{array}$ & $\begin{array}{l}\text { E-Government } \\
\text { e.g. Korea, Ecuador, } \\
\text { Finland, United } \\
\text { States, India, South } \\
\text { Africa }\end{array}$ & $\begin{array}{l}\text { The Integrity Pact } \\
\text { e.g. Argentina, } \\
\text { Pakistan, Nepal }\end{array}$ & $\begin{array}{l}\text { Independent Audit } \\
\text { Function } \\
\text { e.g. Vienna, Namibia }\end{array}$ \\
\hline & $\begin{array}{l}\text { PROOF (The } \\
\text { Public Record of } \\
\text { Operations and } \\
\text { Finance) } \\
\text { e.g. India }\end{array}$ & $\begin{array}{l}\text { Media Training } \\
\text { e.g. Malaysia }\end{array}$ & $\begin{array}{l}\text { Code of Ethics } \\
\text { e.g. South Africa, } \\
\text { Australia, Ethiopia, } \\
\text { India }\end{array}$ & $\begin{array}{l}\text { Independent Anti- } \\
\text { Corruption Agencies } \\
\text { e.g. Botswana }\end{array}$ \\
\hline & & 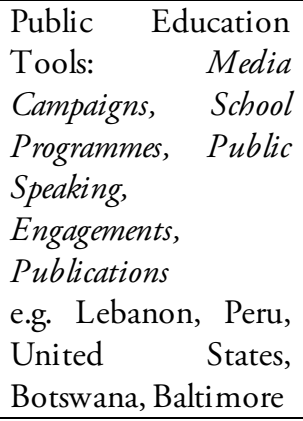 & $\begin{array}{l}\text { Ethical Campaign } \\
\text { Practices } \\
\text { e.g. USA, Azerbaijan }\end{array}$ & $\begin{array}{l}\text { Participatory } \\
\text { Budgeting } \\
\text { e.g. Brazil, Serbia, } \\
\text { Cotacachi }\end{array}$ \\
\hline & & $\begin{array}{l}\text { Public Participation: } \\
\text { Public Hearings, } \\
\text { Study Circles, Citizen } \\
\text { Advisory } \\
\text { Boards, Government } \\
\text { Contacts Committees, } \\
\text { Public Watchdog } \\
\text { Groups } \\
\text { e.g. South Africa }\end{array}$ & $\begin{array}{l}\text { Ethics Training } \\
\text { e.g. Germany, USA }\end{array}$ & \\
\hline
\end{tabular}


South African municipalities have also implemented a code of conduct for councillors to enhance the environment of ethics. For that matter, city councillors for all municipalities in South Africa have to abide by a code of conduct which requires them, among other things, to declare their financial interests, and to report back to the constituencies at regular intervals. Below is the full text of the code, in Schedule 5 of the Municipal Structures Act. Councillors are elected to represent local communities on municipal councils, to ensure that municipalities have structured mechanisms of accountability to local communities, and to meet the priority needs of communities by providing services equitably, effectively and sustainably within the means of the municipality. In fulfilling this role councillors must be accountable to local communities and report back at least quarterly to constituencies on council matters, including the performance of the municipality yin terms of established indicators. In order to ensure that councillors fulfil their obligations to their communities, and support the achievement by the municipality of its objectives set out in section 19 of the Act (City of Johannesburg, 2010: 1), the following Code of Conduct is established (City of Johannesburg, 2010: 1-8):

General conduct of councillors: A councillor must perform the functions of office in good faith, honestly and a transparent manner; and at all times act in the best interest of the municipality and in such a way that the credibility and integrity of the municipality are not compromised.

Attendance at meetings: A councillor must attend each meeting of the municipal council and of a committee of which that councillor is a member, except when leave of absence is granted in terms of an applicable law or as determined by the rules and orders of the council; or that councillor is required in terms of this Code to withdraw from the meeting.

Sanctions for non-attendance of meetings: A municipal council may impose a fine as determined by the standing rules and orders of the municipal council on a councillor for: not attending a meeting which that councillor is required to attend; or failing to remain in attendance at such a meeting. A councillor who is absent from three or more consecutive meetings of a municipal council, or from three or more consecutive meetings of a committee, which that councillor is required to attend, must be removed from office as a councillor. Proceedings for the imposition of a fine or the removal of a councillor must be conducted in accordance with a uniform standing procedure, which each municipal council must adopt for the purposes of this item. The uniform standing procedure must comply with the rules of natural justice.

Disclosure of interests: A councillor must disclose to the municipal council, or to any committee of which that councillor is a member, any direct or indirect personal or private business interest that that councillor, or any spouse, partner or business associate of that councillor may have in any matter before the council or the committee; and withdraw from the proceedings of the council or committee when that matter is considered by the council or committee, unless the council or committee decides that the councillor's director indirect interest in the matter is trivial or irrelevant. A councillor who, or whose spouse, partner, business associate or close family member, acquired or stands to acquire any direct benefit from a contract concluded with the municipality, must disclose full particulars of the benefit of which the councillor is aware at the first meeting of the municipal council at which it is possible for the councillor to make the disclosure.

Personal gain: A councillor may not use the position or privileges of a councillor, or confidential information obtained as a councillor, for private gain or to improperly benefit another person. Except with the prior consent of the municipal council, a councillor may not be a party to or beneficiary under a contract for the provision of goods or services to the municipality; or the 
performance of any work otherwise than as a councillor for the municipality; obtain a financial interest in any business of the municipality; or for a fee or other consideration appear on behalf of any other person before the council or a committee. If more than one quarter of the councillors object to consent being given to a councillor, such consent may only be given to the councillor with the approval of the MEC for local government in the province.

Declaration of interests: When elected or appointed, a councillor must within 60 days declare in writing to the municipal manager the following financial interests held by that councillor: shares and securities in any company; membership of any close corporation; interest in any trust; directorships; partnerships; other financial interests in any business undertaking; employment and remuneration; interest in property; pension; and subsidies, grants and sponsorships by any organisation. Any change in the nature or detail of the financial interests of a councillor must be declared in writing to the municipal manager annually. Gifts received by a councillor above a prescribed amount must also be declared. The municipal council must determine which of the financial interests must be made public having regard to the need for confidentiality and the public interest for disclosure.

Full-time councillors: A councillor who is a full-time councillor may not undertake any other paid work, except with the consent of a municipal council which consent shall not unreasonably be withheld.

Rewards, gifts and favours: A councillor may not request, solicit or accept any reward, gift or favour for voting or not voting in a particular manner on any matter before the municipal council or before a committee of which that councillor is a member; persuading the council or any committee in regard to the exercise of any power, function or duty; making a representation to the council or any committee of the council; or disclosing privileged or confidential information.

Unauthorised disclosure of information: A councillor may not without the permission of the municipal council or a committee disclose any privileged or confidential information of the council or committee to any unauthorised person. For the purpose of this item "privileged or confidential information" includes any information determined by the municipal council or committee to be privileged or confidential; discussed in closed session by the council or committee; disclosure of which would violate a person's right to privacy; or declared to be privileged, confidential or secret in terms of law. This item does not derogate from the right of any person to access to information in terms of national legislation.

Intervention in administration: A councillor may not, except as provided by law interfere in the management or administration of any department of the municipal council unless mandated by council; give or purport to give any instruction to any employee of the council except when authorised to do so; obstruct or attempt to obstruct the implementation of any decision of the council or a committee by an employee of the council; or encourage or participate in any conduct which would cause or contribute to maladministration in the council.

Council property: A councillor may not use, take, acquire or benefit from any property or asset owned, controlled or managed by the municipality to which that councillor has no right.

Duty of chairpersons of municipal councils: If the chairperson of a municipal council, on reasonable suspicion, is of the opinion that a provision of this Code has been breached, the chairperson must authorise an investigation of the facts and circumstances of the alleged breach; give the councillor a reasonable opportunity to reply in writing regarding the alleged breach; and 
report the matter to a meeting of the municipal council. A report is open to the public. The chairperson must report the outcome of the investigation to the MEC for local government in the province concerned. The chairperson must ensure that each councillor when taking office is given a copy of this Code and that a copy of the Code is available in every room or place where the council meets.

Breaches of Code: A municipal council may investigate and make a finding on any alleged breach of a provision of this Code; or establish a special committee to investigate and make a finding on any alleged breach of this Code; and to make appropriate recommendations to the council. If the council or a special committee finds that a councillor has breached a provision of this Code, the council may issue a formal warning to the councillor; reprimand the councillor; request the MEC for local government in the province to suspend the councillor for a period; fine the councillor; and request the MEC to remove the councillor from office. Any councillor who has been warned, reprimanded or fined may within 14 days of having been notified of the decision of council appeal to the MEC for local government in writing, setting out the reasons on which the appeal is based. A copy of the appeal must be provided to the council. The council may within 14 days of receipt of the appeal make any representation pertaining to the appeal to the MEC for local government in writing. The MEC for local government may, after having considered the appeal, confirm, set aside or vary the decision of the council and inform the councillor and the council of the outcome of the appeal. The MEC for local government may appoint a person or a committee to investigate any alleged breach of a provision of this Code and to make a recommendation on whether the councillor should be suspended or removed from office. The Commissions Act, 1947 (Act No.8 of 1947), may be applied to an investigation. If the MEC is of the opinion that the councillor has breached a provision of this Code, and that such contravention warrants a suspension or removal from office, the MEC may suspend the councillor for a period and on conditions determined by the MEC; or remove the councillor from office. Any investigation in terms of this item must be in accordance with the rules of natural justice.

Application of Code to traditional leaders: The above items must be applied to the traditional leader in the same way they apply to councillors. If a municipal council or a special committee finds that a traditional leader has breached a provision of this Code, the council may issue a formal warning to the traditional leader; or request the MEC for local government in the province to suspend or cancel the traditional leader's right to participate in the proceedings of the council. The MEC for local government may appoint a person or a committee to investigate any alleged breach of a provision of this Code and to make a recommendation on whether the right of the traditional leader to participate in the proceedings of the municipal council should be suspended or cancelled. The Commissions Act, 1947, may be applied to an investigation. If the MEC is of the opinion that the traditional leader has breached a provision of this Code, and that such breach warrants a suspension or cancellation of the traditional leader's right to participate in the council's proceedings, the MEC may suspend that right for a period and on conditions determined by the MEC; or cancel that right. Any investigation in terms of this item must be in accordance with the rules of natural justice. The suspension or cancellation of a traditional leader's right to participate in the proceedings of a council does not affect that traditional leader's right to address the council.

Assessment and Monitoring tools (as stated in the table 2) are required to review the implementation of code of conduct at municipal level and further assist to develop the environment of accountability and transparency at the municipal level. The Access to Information tool is a requisite to enhance public participation. The Ethics and Integrity tools 
create a boundary of acceptable actions and behaviour. The Institutional Reforms tool simplifies and clarifies the procedures of good local governance.

The following considerations have to be borne into mind as far as the ethical behaviour of municipal employees is concerned (obtained from Matovu in Plessis, 2003):

Attitudes of local government managers: The focus of local government managers should no longer emphasize managing of financial and material resources only but should also place emphasis on their human capital. One important implication of this attitude would include ensuring improved levels of communication.

In terms of the codes of conduct, for councillors and officials a simple but relevant question revolves around the extent to which the codes are communicated to people...that information dissemination on the code of conduct should form an integral part of the induction process to which new councillors/employees should be subjected. It would in the case of officials also require active involvement of organised labour as representative of employees.

Increased dialogue between communities and the authorities: There is an increased need for local authorities to be participatory especially in the light of the emphasis on developmental local government ... This requires continuous dialogue between authorities and the community. In a country like South Africa the majority of citizens were in the past isolated from issues of governance. There is thus a need to involve and educate local communities on how the authority operates and what they can reasonably expect. In this way the public can also positively impact on councilor and official behaviour if they are aware of the rules applying to those in positions of authority.

Attracting professionals to local government: Emphasis should be on portraying involvement in local government as a professional business. Politicians and officials alike should realise that they have a professional obligation to render services in the best possible ways to the community, their clients.

Integrity within local government: There are increased concerns about corruption in all government spheres. Activities of municipalities should be characterized by openness and honesty towards all stakeholders concerned to ensure the establishment of sustained relations of trust between the authorities and local communities.

The code of conduct is a requisite to avoid maladministration and unethical behaviour at the local sphere of governance. Though there are several factors that underpin the notion of good governance, viz. corruption. Klitgaard (1997: 2) proposed a formula for analyzing the tendency for corruption to exist: $\mathrm{C}=\mathrm{M}+\mathrm{D}-\mathrm{A}$ (Corruption $=$ Monopoly + Discretion - Accountability)

There is a need to implement ethics in order to rectify the above formula for good governance. Moor (2004) further observed that the missing element from the formula is the sense of community, of responsibility for the common good and of ethics.

If ... examine the pattern of existence of corruption in different societies, it might support a modified formula: $C=(M+D-A) / E$, where the denominator $E$ is the ethical ambience (Moor, 2004). 


\section{Concluding remarks}

The following policy points are recommended to further help enforce ethical requirements of public officials:

- Education and training are undoubtedly the backbone of sensitizing and creating awareness of a policy issue. This calls for regular and mandatory training of public officials on issues of ethics. In a number of Commonwealth countries, there exists the parallel institution of South African Management Development Institute (SAMDI, presently known as PALAMA) but which makes it mandatory for every public official to be trained for a Diploma in Public Administration. A prerequisite would be for each candidate to submit research essay on combating unethical conduct.

- The United States of America (USA) legislative system requires all political appointees to be vetted by a Senate Appointments Committee. Considering the gravity and rate of conducts on ethics in South African public service, it is appropriate that South Africa borrows such practice into its system. Such a committee scrutinises the entire fabric and life history of a prospective appointee, and once he/she is recommended, there is a hope that an ethical hurdle has been cleared. The existence of such a committee serves as bloodhound on unethical conduct.

- Further to the policy issue on Appointments Committee should be a policy on Declaration of Assets, on initial appointment, by officials from Director rank upwards. To be administered by the Public Service Commission, officials' social standing would be periodically reviewed.

- Specific functional areas in the public service tend to be prone to unethical conduct. This may be true of tender and bidding functions. A rotation system where tender committee members are announced on the day of tender decisions will help close opportunities for unethical conduct in the process.

- Performance Contracts of Accounting Officers should include degrees of commitment to unearthing unethical conduct; to declare periodically issues that were tackled and rooted out.

- Ultimately, a market-related remuneration may help thwart unethical conduct. The public service is not a profit oriented service institution. Yet, a policy on attractive remuneration is needed for purposes of creating committed and dedicated public officials.

For South Africa, there were a number of lessons learnt with regard to the readiness of municipalities to develop and implement anti-corruption measures. Most notable was that although some municipalities, especially the district municipalities and metropolitan municipalities, have anti-corruption and fraud policies and structures in place, those have proven to be inadequate to effectively fight corruption (Department of Provincial and Local Government, 2008). Consequently, the Local Government Anti-Corruption Strategy (LGACS) developed by the Department of Provincial and Local Government stresses on the following principles: creating a culture within municipalities which is intolerant to unethical conduct, fraud and corruption; strengthening community participation and relationships with key stakeholders. For example, South African Local Government Association, employee representative unions and communities are strategic partners necessary to support the actions 
required to fight corruption in municipalities; deterrence of unethical conduct, taking appropriate action in the event of such irregularities, e.g. disciplinary action, recovery of losses, prosecution, and applying sanctions, which include redress in respect of financial losses (Department of Provincial and Local Government, 2008). In order to fulfil these objectives of good governance, there is the need to strategise measurable implementation plans, conduct sustainable fraud risk assessments and to sensitise the community through education and training regarding good governance and code of ethics.

The article offers recommendations to help promote ethical conduct in local government viz. through research (survey, opinion polls). There is a need to identify the underlying factors that cause corruption in local government. Transparency and accountability are most important to the legitimacy of local officials hence there is a need to form coalitions with stakeholders to stop corruption locally. Much publicity is needed to be given to the art of municipal financial reporting. The hearings at PROPACS (Provincial Public Accounts Committees), of Audit Committees, need to be in the public domain. Auditor-General road shows could be conducted to enlighten municipal public on audit findings and soliciting public partnership in unearthing municipal unethical conduct.

The public sector, according to Lynch (in Raga and Taylor, 2007: 4), like individuals, is constantly changing through new leadership, environmental influences and socio-political development. Government and society cannot promote and enforce ethical behaviour solely through the utilisation of ethical codes of conduct or through the promulgation of a plethora of legislation. Social mindsets are often entangled in a micro-ethic paradigm. People tend to equate moral values and moral norms, which apply only to personal relations structures within which they interact. South Africa needs an organisational culture that not only supports ethical behaviour, but also defines and underpins right and wrong conduct at an individual and institutional sphere.

The Code of Conduct is a requisite to regulate the environment of transparency and accountability. The cases of misconduct which are not expressly provided for in terms of either Code of Conduct may be further regulated by each municipal council in terms of Section 160 of the Constitution, which deals with the internal procedures of a municipal council. For instance, the council would be entitled to incorporate into its standing rules and orders any act of misconduct which is not expressly provided for in the Code of Conduct for Councillors. . It may be argued that the general prohibition contained in item 2 of the Councillors' Code of Conduct is wide enough to cover any type of misconduct which may have the effect of compromising the credibility and/or integrity of the municipality (Nkosi, 2006). It appeared that the phenomenon of ethical conduct in public activities and all the circumstances surrounding them could be subjected to scientific investigations, in order to analyze the implications thereof. This serves as a motivation for the study, in order to research the phenomenon of good local governance within the context of ethics.

\section{References}

Agere, S. 1992. 'The promotion of good ethical standards and behaviour in public services in Africa: the case of Zimbabwe'. Africanus, Vol. 22.

ANC Today. 2005. “ANC Today”. http://www.anc.org.za. Accessed on 28 August 2010. 
Cameron, RS and Stone, AB. 1995. Serving the public: A guide for practitioners (Pretoria: Van Schaik).

City of Johannesburg. 2010. "Code of Conduct for Councillors". http://www.joburg.org.za

Cloete, JJN. 1995. Accountable Government and Administration for the Republic of South Africa (Pretoria: Van Schaik).

Cranston, N., Ehrich, L. and Kimber, M. 2003. 'Ethical dilemmas faced by senior public sector managers: towards an exploratory model'. http://www.gu.edu.au

Democratic Alliance. 2010. "The rot in ANC municipalities: five case-studies of cronyism, corruption and ineptitude". http://www.da.org.za. Accessed on 5 March 2010.

Democracy Development Programme. 2006. 'Towards good governance, ethical conduct and integrity in the second decade of democracy in South Africa'. Introductory Note for the DDP/UKZN Conference, 16-17 October 2006. http://www.ddp.org.za

Department of Provincial and Local Government, 2008. 'Local Government AntiCorruption Strategy'. http://www.dplg.gov.za

Department of Provincial and Local Government, 2008. 'Local Government'. http://www.dplg.gov.za

Department of Public Service and Administration. 2002. "Public Service Anti-Corruption Strategy". http://www.dpsa.gov.za. Accessed on 24 March 2007.

Klitgaard, R. 1997. 'International cooperation against corruption”. http://www.icgg.org

Makrydemetres, A. 2002. 'Dealing with ethical dilemmas in public administration: the 'ALIR' imperatives of ethical reasoning'. http://www.unpan1.un.org

Moor, J. 2004. "Transparency and corruption”. http://ww2.unhabitat.org

Nkosi, V. 2006. 'Ethics and Codes of Conduct in Local Government (Councillors and Municipal Staff Members)'. http://www.ddp.org.za

Plessis, du LM. 2003. 'Promoting ethical conduct and integrity in local government: a South African perspective'. http://www.iiasiisa.be

PoliticalCorruption.net.2009. "Types of corruption found in local government". http://www.politicalcorruption.net. Accessed on 10 August 2009.

Public Service Commission. 1997. "Code of Conduct for Public Servants". http://www.psc.gov.za

Public Service Commission. 2010. "Code of Conduct for Public Servants". http://www.psc.za

Raga, K. and Taylor, D. 2007. 'Impact of accountability and ethics on public service delivery: a South African perspective'. http://www.thepublicmanager.org

Republic of South Africa. 1992. Prevention of Corruption Act (Act 94 of 1992) (Pretoria: Government Printer).

Republic of South Africa. 1994. White Paper on the Transformation of the Public Service 1994 (Pretoria: Government Printer). 
Republic of South Africa. 1996. The Constitution of the Republic of South Africa, 1996 (Pretoria: Government Printer).

Republic of South Africa. 1998. The Local Government: Municipal Structures Act, 1998 (Pretoria: Government Printer).

Republic of South Africa. 2000. The Local Government: Municipal Systems Act, 2000 (Pretoria: Government Printer).

Sindane, A.M. 2009 Administrative Culture, Accountability and Ethics: Gateways in search of the Best Public Service. Journal of Public Administration Vol 44 No. 3

UN-HABITAT. 2004. 'Urban Governance Toolkit Series'. http://www.hq.unhabitat.org

United Nations Development Programme, 2008. 'Introducing good local governance: The Indonesian experience'. http://www.undp.or.id

Urban Governance Toolkit Series. 2004. 'Un-habitat'. http://www.hq.unhabitat.org

Vyas-Doorgapersad, S \& Ababio, EP. 2006. Ethical dilemmas and democratic values: How to reposition institutions for good governance and service delivery. Lournal of Public Administration. Vol. 41. No. 2.2.

Vyas-Doorgapersad, S. 2007. "Corruption in the Public Sector: a comparative analysis". Lournal of Public Administration. Vol. 42. No. 5.

Vyas-Doorgapersad, S., Subban, M. \& Pillay, S. 2008. Ethics for Good Local Governance in South Africa. Paper presented at the IIAS Conference in Uganda.

Walters, S. 2009. "Ethics and leadership for good governance". http://74.6.239.185/search/srpcache? Accessed on 15 August 2010. 